USOBED Uluslararası Batı

Book Review

Kitap İncelemesi
Karadeniz Sosyal ve Beşeri Bilimler

Dergisi, 3(2):235-237

31 Aralık/December, 2019
International Journal of Western Black Sea Social and Humanities Sciences e-ISSN :2602-4594

\title{
ADIYAMAN İLİ VE YÖRESİ AĞIZLARI SÖZ VARLIĞI
}

(Kitap Künyesi: Dr. Burak TELLİ, Dr. Türker Barış BULDUK, Gazi Kitabevi, 1. Baskı, Ankara, Aralık, 2018, 300 Sayfa. ISBN:978-605-344-853-2)

\section{Dr. Mehmet Emin TUĞLUK}

Millî Eğitim Bakanlığ 1

emintugluk@gmail.com

ORCID: 0000-0003-1866-5580

Dil toplumun iletişimini sağlamada en önemli araç olduğu gibi yaşadığı kültürün de en temel ögesidir. Dildeki söz varlığ1 ve bu söz varlığını bünyesinde barındıran sözlükler toplumun kültür algısını yansitan en temel kaynaklardır. Sözlüklerin dolayısıyla dilin en büyük başvuru kaynağı hiç şüphesiz ağızlardır.

Türkçede sözlük ve sözlükçülüğün geçmişi eskiye dayanırken ağız araştırmalarının tarihi çok eskiye dayanmaz. Bu alanda yapılan kapsamlı ilk çalışma 1932 yılında kurulan ve günümüzde Türk Dil Kurumu adını alan Türk Dili Tetkik Cemiyeti tarafından yapılmıştır. Türk Dili Tetkik Cemiyetinin yaptığı ilk işlerden biri 1933-1935 yılları arasında 150 bin kelimeyi derlemek ve derlediği bu kelimeleri 1939-1949 yılları arasında Türkiye'de Halk

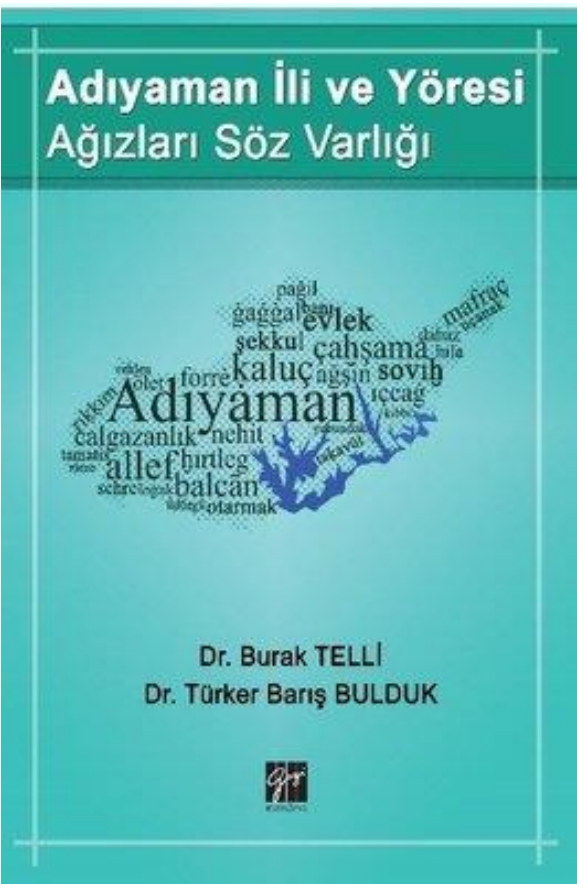
Ağzından Söz Derlemeler Dergisi'nde yayımlamak olmuştur. Türk Dil Kurumu 1952-1960 yılları arasında eldeki malzemesini daha bilimsel bir şekilde güncellemiş ve sekiz yıllık bir sürede 450 bin kelime derlemiştir. Daha önce toplanan 150 bin kelimeyle birlikte yoğrulan bu 450 bin kelime, 13 ciltten oluşan Derleme Sözlüğünün temelini oluşturmuştur. Derleme Sözlüğünün $A-K$ arası ciltleri 1963-1975 yılları arasında $K$ ile $Z$ arasındaki ciltleri de 1979 yılında tamamlanmıştır. Sözlüğün Ek-I cildi ise 1982 yılında yayımlanmıştır. Bunu izleyen yıllarda ağız çalışmaları büyük ilerlemeler kaydetmiştir. Günümüzde Türkiye Türkçesi Ağızlarının çok büyük bir kısmı üzerine bilimsel çalışmalar gerçekleştirilmiş durumdadır. Bugün çalışılmayan az sayıda ağız bölgesi kalmıştır. Bunların da

Citation/Atıf: Tuğluk, M. E. (2019). Adıyaman İli ve Yöresi Ağızları- Kitap İncelemesi. Uluslararası Batı Karadeniz Sosyal ve Beşerî Bilimler Dergisi, 3(2),235237
Geliş (Received) : : 11.12.2019

Kabul (Accepted) : 12.12.2019

Yayın (Published) : 31.12.2019 
çalışılmasıyla Türkiye Türkçesi Ağızları söz varlığının daha net bir şekilde ortaya çıkarılması mümkün olacaktır. Gelinen noktada Türkiye Türkçesi ağızları üzerine yapılan bilimsel çalışmalar Türkçeyle ilgili daha ayrıntılı konulara kaynaklık etmekte ve Türkçenin zenginliğini ortaya çıkarmaktadır. Bu konuda son dönemde yapılan çalışmaların biri de söz varlığı ile ilgili çalışmalardır.

Adıyaman ili ve yöresi üzerine hazırlanmış kitap ve lisansüstü tez düzeyinde pek çok çalışma bulunmaktadır. Bu çalışmaların en kapsamlısı Serdar Yavuz tarafından hazırlanan Adıyaman İli ve Yöresi Ağızları adlı kitaptır. Anılan bu çalışmalarda sözlük bölümü de bulunmaktadır. Adıyaman İli ve Yöresi Ağızları Söz Varlığı eserinin hazırlanmasında bu yazılı kaynaklardaki sözlüklerden yararlanılmıştır. Ayrıca yazılı bu kaynaklar dışında sahada derlenmiş sözcüklere de yer verilmiştir.

Eserin başında Sözlüğün Hazırlanış Düzenini belirten bir bölüm bulunmaktadır. Bu bölümde sözlüğün hazırlanmasıyla ilgili çeşitli bilgilere yer verilmiştir. Buna göre sözlükte 4032 adet madde baş1 sözcük yer almaktadır. 4032 adet madde başı sözcükten bölgeye ait Derleme Sözlüğünde yer alan 81 adet sözcük tespit edilmiştir. Sözlükte yer alan madde başları transkripsiyon alfabesiyle, küçük harfle başlatılmış ve koyu renkle yazılmıştır.

Sözlükte Adıyaman ili ve Yöresine ait pek çok deyime de yer verilmiştir. Sözlükte ilgili maddede öncelikle deyimin anlamı verilmiş daha sonra deyim $\left(^{*}\right)$ işareti ile örnek bir cümlede kullanılmıştır. Sözlükte ayrıca her madde başından sonra sözcügün türü ayraç içinde kısaltma kullanılarak gösterilmiştir.

Sözlükte madde başı olarak verilen sözcügün birden fazla anlamı varsa ve bu anlamlar farklı sözcük türünde ise sözcüğün ilgili anlamdaki türü anlamın açıklamasının başında ayrı ayrı verilmiştir. Ancak sözcügün farklı anlamlardaki türü aynısa madde başı yanında bir kez verilmiştir.

Sözlükte bulunan 4032 madde başından 200 adedinin başka bir madde başında farklı yazılışı bulunmaktadır. Bu madde başlarını bk. kısaltması ile yazılmıştır.

Sözlügün hazırlanış düzeninden sonra eserin hazırlanmasında yararlanılan Taranan Eserler ve Kısaltmalar yer almaktadır. Bu bölümde eserin hazırlanılmasında yararlanılan on dört eser / tez ismine yer verilmiştir. Taranan Eserler ve Kısaltmalardan sonra eserin Sözlük kısmı başlamaktadır. Eserin Sözlük kısmında isim, fiil, zamir, sıfat, zarf vb. sözcükler alfabetik sıraya göre sıralanmıştır. Sözlükte dikkat çeken bazı sözcük türü örnekleri şu şekildedir:

İsim: abuat (“bilmiş kimseler” için kullanılan bir ifade), Ǿaboş (Adıyaman’ın yerlileri için kullanılan bir kelime), behre (hüner), hepek (baca kapağı), ķamka (ağaç ve tahta kıymığı), dümbüldeg (yerden kaynayarak çıkan suyun çıkış yerinde bulunan taş) 
Fiil: basırmak (kapıyı sürgülemek, desteklemek, mandalamak), fincıtmak (firlatmak), gısdalamak (araya bir şey sıkıştırmak, hırmahış olmak (bir şeyin çok ezildiğini belirten bir ifade), kekeşme (uyuşma)

Zamir: nès (ne), se (sen), vile (filan)

Sıfat: ağşın (uzak), cılķ (işe yaramaz, çürük), dollaz (avare, aylak kimse), hefgir (savurgan), körefem (aptal, budala anlamında bir söz)

Zarf: alemeşkere (iyiden iyiye), beremer (beraber), fermide (acele bir şekilde), ġın ġırısaḳ (tek ayakla yürümek)

Edat: hhel (hele), hıldır çıldır (“eh işte idare eder” anlamında bir ifade), ketlek (bu kadar, kadar), seki (için edatı yerine kullanılan bir sözcük)

Bağlaç: ke (ama), ele belle ki ("varsay ki farz et ki” anlamında kullanılan bir ifade)

Ünlem: ahane ("işte orada" anlamında bir ünlem), bi kele (şaşırma, hayret bildiren bir ünlem), keşkele (keşke), tehao (“oho neler neler” anlamında bir ünlem)

Eser, Adıyaman ili ve yöresi ağızları üzerine hazırlanmış müstakil ilk ağız sözlüğü olması bakımından Adıyaman yöresine ait söz varlığının tespitinde büyük bir boşluğu doldurmuştur. 